\title{
Teacher's Digital Competencies. A Systematic Review in the Latin- American Context
}

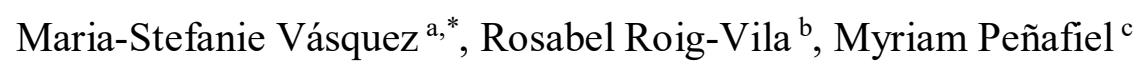 \\ ${ }^{a}$ Departamento de Estudios Organizacionales y Desarrollo Humano, Escuela Politécnica Nacional, Quito, 170525, Ecuador \\ ${ }^{b}$ Facultad de Educación, Universidad de Alicante, Alicante, 03690, Spain \\ ${ }^{c}$ Departamento de Informática y Ciencias de la Computación, Escuela Politécnica Nacional, Quito, 170525, Ecuador \\ Corresponding author: "maria.vasquez@epn.edu.ec
}

\begin{abstract}
Currently, more than 290 million students in the world are not attending classes due to the pandemic caused by COVID-19. In this sense, many educational centers have adapted classroom teaching to a non-classroom setting in response to the crisis. However, the change of modality from face-to-face to virtual education cannot suppose only a decision in which it is intended to replace the first one using some computer tools as video conferences. With this preamble, the need to systematically map digital competencies in Latin American higher education teachers raises since there are no records of the status of teacher's digital competencies in this part of the world before the pandemic. Therefore, this work examines the scientific literature published in the Web of Science, Scopus, ACM, IEEE, and Science Direct databases from 2004 until 2019. The Kitchenham method applied for the systematic mapping allowed determining quantitative and qualitative results such as year of publication and documentary sources with the most significant number of papers. The main contribution of this research is the areas found of teachers' digital skills that are considered relevant in the Latin American context and its differences with other models. Finally, a discussion of the results and conclusions serves as a starting point for future research in other geographic areas and preliminary information to determine teachers' training needs to face the crisis.
\end{abstract}

Keywords - Digital competencies; digital competencies; digital skills; higher education; content analysis; bibliometric; Latin America.

Manuscript received 15 Jul. 2020; revised 26 May 2021; accepted 10 Jul. 2021. Date of publication 31 Dec. 2021. IJASEIT is licensed under a Creative Commons Attribution-Share Alike 4.0 International License.

\section{INTRODUCTION}

According to UNESCO, more than one and a half billion students, representing more than $90 \%$ of the world's students, will not be attending face-to-face classes until the end of April 2020 due to the pandemic caused by COVID-19 [1]. In this sense, many educational centers, including Higher Education institutions (HEI), have pro-moted an adaptation of face-toface teaching to a virtual context in response to the crisis. However, the change from face-to-face to virtual modality cannot only be a decision in which it is intended to supply the teacher's presence with the creative use of some computer tools [2]. This process requires substantial reforms in the teaching-learning process that include changes in educational models, development of digital competencies (DC) in all stakeholders, changes in institutions' infrastructure, and perhaps most importantly, students' ability to access education without turning this into a discriminatory gap.

With this preamble, and given the existence of relevant research at the global level, specifically in Europe[3]-[6], the need for systematic mapping of the digital competencies of HEI teachers in the Latin American context arises [2], [7], [8]. Thus, teacher training must be assumed integrally. It is crucial to guarantee a change in the teaching-learning processes to fulfill the multiple requirements resulting from this global crisis generated by the pandemic [3]. Therefore, this study will focus on using the concept of "digital competence" as a keyword, discriminating its possible synonyms to avoid confusion. For this reason, it is necessary to start with a definition that encompasses and clarifies the concept of digital competencies and their relationship with the university teaching staff:

\section{A. Digital Competencies: Meaning and its Importance in Current Education.}

The phrase "digital skills" has several related terms such as digital literacy, computer literacy, digital skills, literacy skills, computer literacy, and despite their meanings are different, they can be used interchangeably [8], [9]. For example, UNESCO, in its report "Digital skills for life and work" [10], 
defines digital skills as "a range of different abilities, many of which are not only 'skills' per se, but a combination of behaviors, know-how, work habits, character traits, dispositions, and critical understandings." Meanwhile, the European Union Council describes them as: "the safe and critical use of technologies in the information society, for work, leisure and communication"[3].

Cabero-Almenara [6] suggests that current teachers should have adequate training to guide their students and future generations in the process of technology-assisted learning and integrate these tools into the curricular content. Furthermore, these skills must be developed beyond digital literacy because it is necessary to master other additional components such as informational, communicative, audiovisual, and technological skills [7].

Miscellaneous literature reviews characterize digital skills such as techniques, information, communication, collaboration, creativity, critical thinking, and problemsolving [11]. A characteristic of overtime digital competence has been transformed from an exclusively operational and technical approach in the use of technology towards cognitive, critical, and responsible perspectives oriented to knowledge [8]. When defining digital competence concerning teachers' professional development, the concept is considered an individual teacher's capacity to implement ICT in learning activities. All this is done to improve knowledge and students' understanding through a holistic model that combines analytical levels and prerequisites for individual ability [12].

\section{B. Teacher's Digital Competencies in Higher Education.}

The determination of those competencies that teachers must demonstrate in their role as students' trainers, the communication skills in their workplace, and the development of materials for the teaching-learning process are concerns that have led to many kinds of research [13]-[15]. As a result of these works' compendium, the European Digital Competence Framework for Teachers «DigCompEdu» was proposed. This document defines teaching competencies in the following terms: professional commitment, digital resources, digital pedagogy, evaluation, and feedback, empowering students, and facilitate digital skills [5].

Considering that governments have established guidelines so that students will not be left out of their educational processes through virtual platforms, teachers will be expected to show their proficiency levels in these digital competencies or seek self-education. This research aims to establish a baseline around the teachers' digital competencies in Latin American HEI to identify the priority areas or dimensions of this region in which digital competencies were framed before the pandemic. Once the areas are identified, a training process will allow teachers to adapt to new academic needs and develop an active, critical, and realistic attitude towards technologies and their use in the classroom.

To comply with the proposed research, here are the stated objectives, resulting from a systematic reflexive process:

- To carry out an exhaustive review in the primary databases of articles related to digital competencies for teachers in Latin America, the result was the abstraction of 15 documents from a total of 601 articles from seven databases.
- To determine the most relevant areas of analysis of digital competencies in the Latin American context, where the use of technology, knowledge construction, information and communication, professional development, axiological and social competencies were identified as the main ones.

- To determine the relationship of the areas found with teachers' digital competencies models in other geographic regions such as the United States and the European Union, which already have significant progress in these issues.

\section{MATERIAL AND MethoD}

Systematic mapping or scoping studies are designed to overview a research area through the classification categories [16]. The objective is to search for topics studied, where they have been published, by whom, and how the research was carried out. The result of a mapping study is an inventory of documents on the area assigned to a classification. Therefore, a systematic mapping overviews the topic's scope and explores gaps and research trends [17].

\section{A. Process Development.}

According to Kitchenham [18], a systematic mapping consists of three generic phases: planning, conducting, and reporting the review. In Fig. 1. each stage is detailed.

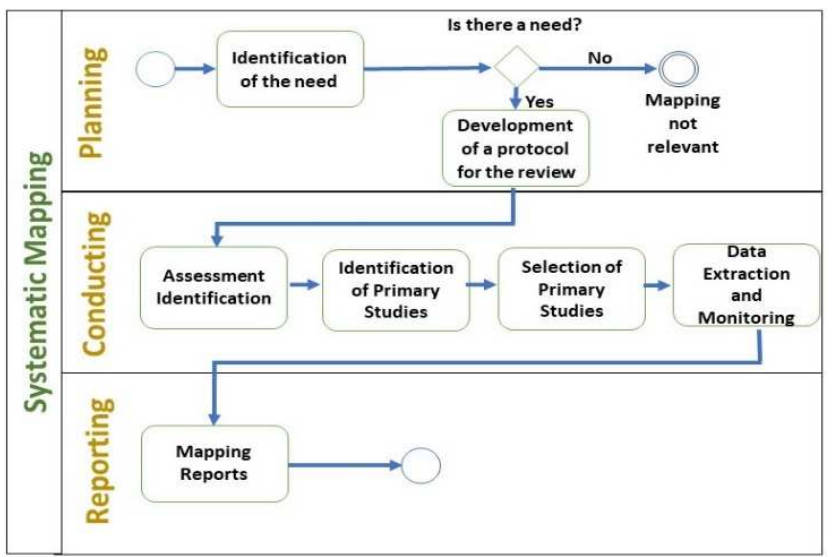

Fig. 1 Systematic Mapping Process

\section{B. Application.}

Carrying out this Systematic Mapping will determine the status of the investigations carried out around Digital Competencies in Higher Education, pointing to Latin America as a priority context and considering as baseline in temporary space all those publications made since 2004 and before the appearance of COVID-19. The objective is to determine the number of studies that have been carried out on the subject, the sources, methods applied, and obtain all the information that may serve as a guide for subsequent replications.

Next, the process carried out to apply the Systematic Mapping using the State of the Art through Systematic Review (StArt) tool is described. This application itself defines the phases and protocols based on the publications of Kitchenham [17]. 
1) Phase 1 Planning the Review: As per Fig. 1, this phase has two main activities: Identifying the need for reviewing and developing the protocol for the review.

- Identification of the need for reviewing. Initially, the period 2004-2019 was pertinent, considering that the objective is to search for all articles about "digital competencies" and "higher education" before COVID19. The first search test carried out 1575 articles approximately; thus, if the number of papers had been minimal, it was to be considered that the topic is not mature, which is not the case. Therefore, there is sufficient research in the area, and it is advisable for the systematic mapping process. Once the number of records found was established as valid, the systematic mapping process started.

- Mapping protocol. The revision protocol was registered in the StArt tool, establishing the objective, main question, keywords and synonyms, source selection criteria, research languages, and source search methods.

a) Objective and main questions: The review's objective was defined as identify the state of the art of teachers' digital competencies in the Latin American context. The main question is How were the digital competencies developed in Latin America between 2004 and 2019?

b) Studies languages: Studies carried out in English and Spanish were considered.

c) Keywords and synonyms: The various terms widely used to identify digital competencies [8] were included: "competencias digitales," "digital skills," "digital competences," y "digital competencies." Additionally, the following terms were included: "docente", "teacher", "professor", "profesor", "educación superior", "higher education", "university".

d) Selection criteria for sources and their search methods: The most relevant and widely used databases such as IEEE, Web of Science (WOS), Scopus, Science Direct, PROQUEST, and ACM are considered. The search was carried out through commands and with the use of Boolean signs.

2) Phase 2 Carrying out the Mapping: Four activities were carried out in the second phase.

- Assessment Identification. Among the studies of states of the art and systematic mapping initially identified, [2] presents a literature review in digital skills in Higher Education in Brazil. This article concludes that Higher education institutions only serve in information and data literacy, collaboration and communication, and problem-solving, identifying a gap between integrating security areas and creating digital content into the academic context. Several studies could be mentioned to highlight the need to carry out this research. Among them, Cabero's [5] research stands out, where it considers DigCompEdu TDCs as the reference framework for the classification and characterization of digital teaching competencies in the European Union.

- Identification of primary studies. The databases considered for this study were extracted in RIS and Bibtex format on various dates, and the last group was on November 30th, 2019. The initial results obtained and exported to the StArt application, using "higher education" and "digital competencies" as criteria were:

a) Science Direct (303 articles),

b) IEEE (eight articles),

c) Web of Science (163 articles),

d) ACM (12 articles),

e) SCOPUS (158 articles) and,

f) PROQUEST: If a similar search string, as databases described above, were used, 931 articles would have been yielded. Therefore, the search was refined, and additionally, the teacher criterion was considered giving 21 articles as a result.

- Selection of primary studies. With 665 articles, 64 duplicates are eliminated, thus obtaining 601 papers for the selection process. Subsequently, the abstracts of each document are analyzed. By applying the following inclusion and exclusion criteria, 62 articles were obtained for the Extraction and Follow-up process. The inclusion criteria consider the studies carried out on digital skills in Higher Education and teachers. While the exclusion considers some aspects, as follows:

a) the articles, which are not related to the educational context (e.g., Industry, medicine, etc.);

b) articles that discuss digital skills for primary and secondary education and others other than higher education (e.g., disabled groups);

c) studies carried out on students; specific studies on ICT.

d) other particular studies (e.g., web 2.0 tools, Internet, etc.) and.

e) studies not related to teachers (parents, senior citizens, etc.).

- Data extraction and monitoring. In this final process of the Conducting Phase, the country in which each research was carried out was analyzed, accepting only articles made in Latin American countries. Finally, 15 documents were obtained to monitor the data. The results present the type of study, the data collection technique, the framework considered, and the TDC used in each publication within the data monitoring.

3) Phase 3 Mapping Report: Finally, data synthesis was developed.

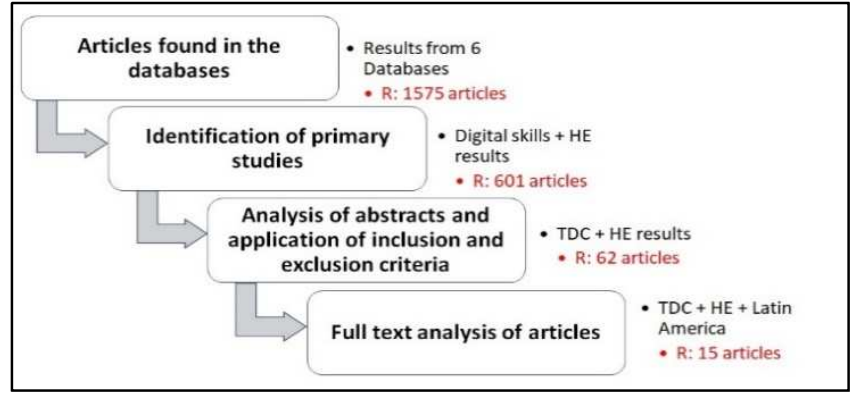

Fig. 2 Summary of the process carried out until obtaining the results of the Systematic Mapping

The synthesis process applied the inclusion/extraction criteria based on the abstract analysis, obtaining 62 documents from the 601 articles identified. In addition, we performed a one-by-one reading of the full text to get 15 
papers on TDC in Latin America. The synthesis of the methodology used is presented in Table 1.

TABLE I

SYNTHESIS OF THE METHODOLOGY USED

\begin{tabular}{|c|c|c|c|c|}
\hline Code & Reference & Country & $\begin{array}{c}\text { Type of research/ } \\
\text { Sample }\end{array}$ & $\begin{array}{c}\begin{array}{c}\text { Data collection } \\
\text { tool }\end{array} \\
\end{array}$ \\
\hline A1 & [19] & $\begin{array}{l}\text { Dominican } \\
\text { Republic }\end{array}$ & $\begin{array}{l}\text { Quantitative / } 121 \\
\text { teachers }\end{array}$ & Survey \\
\hline $\mathrm{A} 2$ & [20] & Mexico & Mixed/ 47 teachers & $\begin{array}{l}\text { Survey, } \\
\text { Interview, Focus } \\
\text { Group }\end{array}$ \\
\hline A3 & [21] & Peru & $\begin{array}{l}\text { Qualitative/Not } \\
\text { available }\end{array}$ & $\begin{array}{l}\text { Descriptive } \\
\text { Analysis }\end{array}$ \\
\hline A4 & [22] & Ecuador & $\begin{array}{l}\text { Quantitative / } 178 \\
\text { teachers }\end{array}$ & Survey \\
\hline A5 & [23] & Mexico & Mixed/Not available & $\begin{array}{l}\text { Survey, } \\
\text { Interview, Focus } \\
\text { Group, and } \\
\text { Debate }\end{array}$ \\
\hline A6 & [24] & Mexico & $\begin{array}{l}\text { Qualitative/Ten } \\
\text { teachers }\end{array}$ & $\begin{array}{l}\text { Observation, } \\
\text { Discussion, } \\
\text { Focus Group }\end{array}$ \\
\hline A7 & {$[25]$} & Venezuela & $\begin{array}{l}\text { Qualitative/Seven } \\
\text { teachers }\end{array}$ & $\begin{array}{l}\text { Interview and } \\
\text { Observation }\end{array}$ \\
\hline A8 & [26] & $\begin{array}{l}\text { Ecuador } \\
\text { and Spain }\end{array}$ & $\begin{array}{l}\text { Qualitative/Not } \\
\text { available }\end{array}$ & $\begin{array}{l}\text { Literature } \\
\text { Review }\end{array}$ \\
\hline A9 & {$[27]$} & Brasil & $\begin{array}{l}\text { Quantitative/67 } \\
\text { teachers }\end{array}$ & Survey \\
\hline A10 & [28] & Colombia & $\begin{array}{l}\text { Quantitative/236 } \\
\text { teachers }\end{array}$ & Survey \\
\hline A11 & [29] & Mexico & Mixed/863 teachers & Survey \\
\hline A12 & {$[30]$} & Ecuador & $\begin{array}{l}\text { Qualitative/Not } \\
\text { Available }\end{array}$ & $\begin{array}{l}\text { Descriptive } \\
\text { Analysis }\end{array}$ \\
\hline A13 & {$[31]$} & Ecuador & $\begin{array}{l}\text { Quantitative/87 } \\
\text { teachers }\end{array}$ & Survey \\
\hline A14 & {$[32]$} & $\begin{array}{l}\text { Ecuador, } \\
\text { Chile and } \\
\text { Mexico, } \\
\text { and others }\end{array}$ & $\begin{array}{l}\text { Qualitative/Not } \\
\text { available }\end{array}$ & $\begin{array}{l}\text { Descriptive } \\
\text { Analysis }\end{array}$ \\
\hline A15 & [33] & $\begin{array}{l}\text { Mexico, } \\
\text { Chile, and } \\
\text { Spain }\end{array}$ & $\begin{array}{l}\text { Qualitative/Six } \\
\text { teachers }\end{array}$ & $\begin{array}{l}\text { Interview and } \\
\text { Debate }\end{array}$ \\
\hline
\end{tabular}

\section{RESULTS AND DISCUSSION}

\section{A. Results}

The results obtained after carrying out the systematic mapping process are presented in this section based on the proposed research questions. It is observed that in 299 sources, the 601 articles related to TDC and HE, identified in the six databases, were published whether if they are journals or conference proceedings. The sources with the most significant number of publications on the subject are Procedia-Social and Behavioral Sciences (69), Computers \& Education (40), Computers in Human Behavior (22), Procedia Computer Science (11), ACM International Conference Proceeding Series (10), Teaching and Teacher Education (8), Telecommunications Policy (8), Telematics and Informatics (8), International Journal of Educational Technology in Higher Education (7). Concerning the number of articles published, there was a significant increase in scientific production starting in 2010, when 19 articles were published. From then, it continued to increase until reaching 113 articles in 2019.

Regarding the rejected documents in the selection process, most retracted articles focus on students (36\%) or specific studies (32\%). The particular studies included tools, learning methodologies, and others (e.g., b-learning, web 2.0, Internet,
MOOCs, game-based learning, social media, IoT, others) related to digital competencies that do not deal with them completely. The ICT studies are also specific; however, they are the most representative, so they were independently measured $(7 \%)$. Therefore, it has to be considered that an article could have one or more exclusion criteria simultaneously.

In the extraction process, we were able to visualize that finally, only 15 articles were considered related to the analysis of 18 countries for the Latin American context. Two papers refer to the United States, and 50 articles are studies from European countries. Several pieces of research included two or more countries. Regarding the distribution by country, Spain (19) stands out, followed by Mexico (6) and Ecuador (5). Countries as England, Italy, Norway, Sweden, and Ukraine have three articles; Chile, Croatia, Finland, and USA (2) and Germany, Belgium, Brasil, Colombia, Denmark, Greece, Holland, New Zealand, Peru, Poland, Portugal, Dominican Republic and, Venezuela, only one.

On the other hand, of the analysis obtained from the 15 Latin American articles, a distinction was made between the applied methodology and the results obtained from each one. Table 1 shows that $46 \%$ of the studies carried out regarding the methodology are quantitative, while $33 \%$ correspond to qualitative and $21 \%$ to mixed methods. The predominant data collection techniques are surveys; however, $26 \%$ of the research are non-experimental descriptive analyses.

Finally, Table 2 summarises the authors of the theoretical framework of digital competencies (DC). Each article was based and the dimensions or areas of digital teaching competencies used in each investigation.

TABLE II

SYNTHESIS OF TEACHERS' DIGITAL COMPETENCES

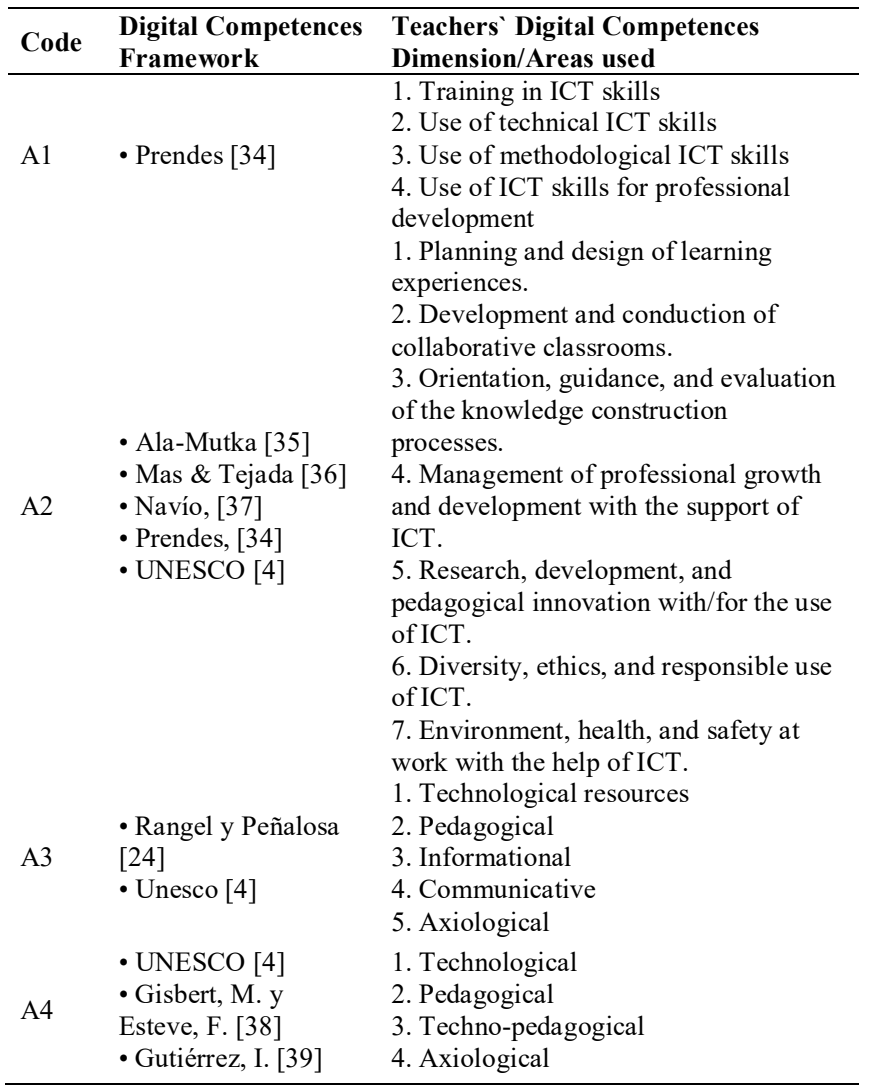




\begin{tabular}{|c|c|c|}
\hline Code & $\begin{array}{l}\text { Digital Competences } \\
\text { Framework }\end{array}$ & $\begin{array}{l}\text { Teachers` Digital Competences } \\
\text { Dimension/Areas used }\end{array}$ \\
\hline & & $\begin{array}{l}\text { 5. Academic management } \\
\text { 6. Ethical and social aspects }\end{array}$ \\
\hline A5 & Not Available & $\begin{array}{l}\text { 1. Intellectual } \\
\text { 2. Social } \\
\text { 3. Organisational and cultural fields } \\
\text { 4. Guided by critical reflection and } \\
\text { oriented to innovation } \\
\text { 5. Knowledge construction } \\
\text { 6. Collaboration }\end{array}$ \\
\hline A6 & $\begin{array}{l}\text { - Hernández [40] } \\
\text { - Marquez [41] } \\
\text { - Unesco [4] } \\
\text { - Ministerio de } \\
\text { educación de Chile } \\
\text { [42] }\end{array}$ & $\begin{array}{l}\text { 1. Technological dimensions } \\
\text { 2. Informational } \\
\text { 3. Axiological } \\
\text { 4. Pedagogical } \\
\text { 5. Communicative }\end{array}$ \\
\hline A7 & $\begin{array}{l}\text { - López [43] } \\
\text { - European } \\
\text { Parliament and } \\
\text { Council [3] }\end{array}$ & $\begin{array}{l}\text { 1. ICT appropriation } \\
\text { 2. Effective and efficient information } \\
\text { analysis } \\
\text { 3. Evaluate the information and its } \\
\text { sources in a critical way }\end{array}$ \\
\hline A8 & Not Applicable & Not Applicable \\
\hline A9 & • Joly e Rueda [44] & $\begin{array}{l}\text { 1. Basic tools and communications } \\
\text { 2. Productivity concepts and tools } \\
\text { 3. Troubleshooting tools }\end{array}$ \\
\hline A10 & $\begin{array}{l}\text { - Unesco [10] } \\
\text { - Ministerio de } \\
\text { educación de Chile } \\
\text { [42] } \\
\text { - Ministerio de } \\
\text { educación de } \\
\text { Colombia [45] } \\
\text { - Lorenzo, Pomares y } \\
\text { Roig [46] }\end{array}$ & $\begin{array}{l}\text { 1. Technological } \\
\text { 2. Communicative } \\
\text { 3. Pedagogical } \\
\text { 4. Investigative } \\
\text { 5. Management }\end{array}$ \\
\hline A11 & $\begin{array}{l}\text { - Ferrari [47] } \\
\text { - Aesaert, et al., [48] }\end{array}$ & $\begin{array}{l}\text { 1. Basic computer management, } \\
\text { 2. Fluent Internet use } \\
\text { 3. Social media use, } \\
\text { 4. Knowledge of digital tools } \\
\text { 5. Materials for teaching } \\
\text { 6. Software text processing skills }\end{array}$ \\
\hline A12 & $\begin{array}{l}\text { - Cabero y Llorente } \\
\text { [6] } \\
\text { - UNESCO [4] } \\
\text { - Ferrari [47] }\end{array}$ & $\begin{array}{l}\text { 1. Knowledge in ICTs } \\
\text { 2. ICT skills } \\
\text { 3. Attitudes required when using ICT }\end{array}$ \\
\hline A13 & $\begin{array}{l}\text { - UNESCO [4] } \\
\text { - ISTE [38] } \\
\text { - Leicester City } \\
\text { Council [3] } \\
\text { - Pozos Pérez [31] } \\
\text { - Ministerio de Chile } \\
\text { [42] } \\
\text { - Ministerio de } \\
\text { Educación de } \\
\text { Colombia [31] } \\
\text { - Lázaro y Gisbert } \\
\text { [49] }\end{array}$ & $\begin{array}{l}\text { 1. Information, } \\
\text { 2. Communication } \\
\text { 3. Content creation } \\
\text { 4. Security } \\
\text { 5. Troubleshooting }\end{array}$ \\
\hline A14 & $\begin{array}{l}- \text { European } \\
\text { Commission [3] } \\
\cdot \text { M. Rieckmann [50] }\end{array}$ & $\begin{array}{l}\text { 1. Language and cultural competence } \\
\text { 2. Communication skills, social } \\
\text { intelligence, soft skills } \\
\text { 3. Pedagogy and pedagogical tools } \\
\text { 4. Ability to manage the line between } \\
\text { work and free time } \\
\text { 5. Problem-solving, anticipatory and } \\
\text { critical thinking, meaning-making }\end{array}$ \\
\hline A15 & $\begin{array}{l}\text { - Carrera \& Coiduras } \\
{[31]} \\
\text { - Rangel [24] } \\
\text { - Prendes et al. [34] } \\
\text { - Tejada \& Pozos [20] }\end{array}$ & $\begin{array}{l}\text { 1. Teacher professional development } \\
\text { 2. Evolution of TDC } \\
\text { 3. TDC areas } \\
\text { 4. Critical appraisal of the use of ICT in } \\
\text { Higher Education }\end{array}$ \\
\hline
\end{tabular}

\section{B. Discussions}

As a summary of the research carried out, the authors mentioned above agree that digital competencies, as their name indicates, do not refer only to the use of ICT in a technical way, but to the set of knowledge, abilities, skills, attitudes, and values generated from and based on ICT. Additionally, they show that in Latin America, the most relevant teachers' digital competencies in this region are technological, communicational-social, uses of information, multimedia literacy, pedagogy, ethical-culturalenvironmental, and management academic skills.

On the other hand, the importance of digital skills in all areas is evidenced in these works. When speaking of citizen training, it is mentioned that digital competencies (DCs) will allow empowerment perspectives about intrinsic social aspects such as politics, economy, and employability [51][56]. In the social sphere, DCs provide the ability to take advantage of the wealth of new possibilities associated with digital technologies in the modern knowledge society [8]. The educational field is not the exception; the new digital education will bring consequences for that society that underestimates it [17]. "It is evident that a teacher cannot make a student develop competence that he does not possess in-depth" [57]. Therefore, the repeated urgent need for training in digital competencies and the need for continuous support and accompaniment for adequate ICT integration in university teaching activity is visible [7].

Fig. 3 summarizes the areas or dimensions of application and use of teachers' digital skills that are the most relevant. Again, it is possible to observe a clear emphasis on acquiring digital skills focused on constructing knowledge, using technology, and managing information and communication.

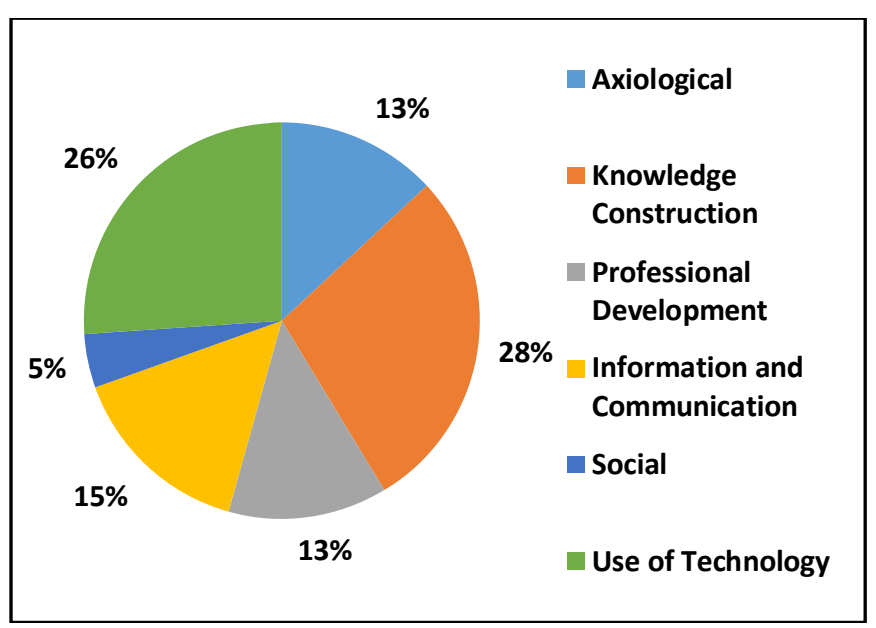

Fig. 3 TDC Latin American Areas (Own Elaboration)

Currently, there are already established models as a guide for the development of digital competencies, among the best known are the model of the International Society for Technology in Education (ISTE) of the United States, the model of the National Institute of Educational Technologies, and Teacher Training (INTEF) of Spain and the European Framework of Digital Competence for Educators (DigCompEdu). 
TABLE III

MODELS AREAS

\begin{tabular}{ccl}
\hline Ref. Model & Code & \multicolumn{1}{c}{ Areas } \\
\hline & 1 & Computational Thinking \\
& 2 & Equity Leader \\
ISTE & 3 & Collaborating Around Computing \\
& 4 & Creativity \& Design \\
& 5 & Integrating Computational Thinking \\
\hline & 6 & Digital Content Creating \\
INTEF & 7 & Security \\
& 8 & Troubleshooting \\
& 9 & Information and Information Literacy \\
& 10 & Communication and collaboration \\
\hline & 11 & Professional Engagement \\
DIGCOMP & 12 & Digital Resources \\
EDU & 13 & Teaching and Learning \\
& 14 & Empowering Learners \\
& 15 & Facilitating Learners'Digital Competences \\
& 16 & Assessment \\
\hline Latin & 17 & Professional Development \\
American & 18 & Knowledge Construction \\
Areas & 19 & Information and Communication \\
& 20 & Social \\
\hline & 21 & Axiological \\
\hline & &
\end{tabular}

Table III summarizes the main areas considered in the models mentioned above. Additionally, a code was assigned to relate them [58]-[60]. Using network theory, Fig. 4. shows the closest relationships between the various areas of each model, thus identifying five communities through an undirected graph.

Each model tends to be grouped. Still, having carried out a systematic review of the areas in Latin America, given the diversity of the reference models used for each study, it is demonstrated that all areas were considered, hence their representativeness.

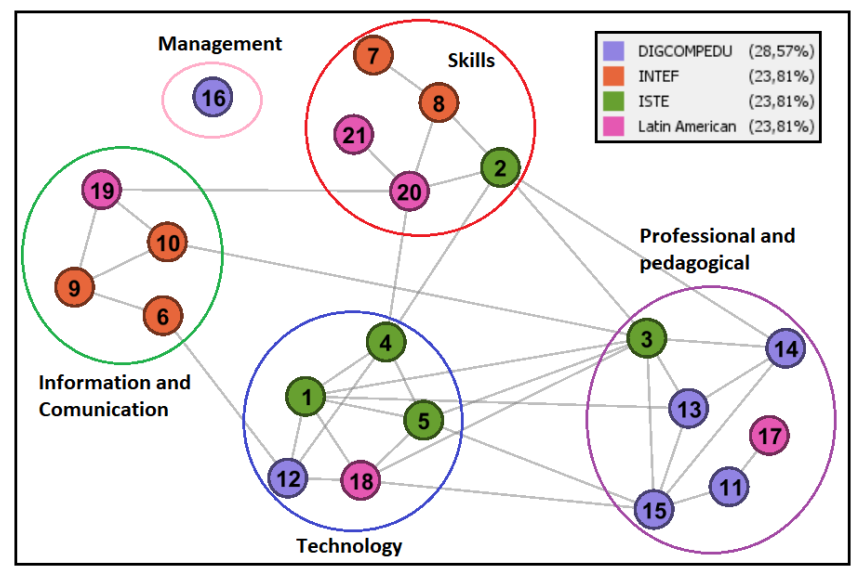

Fig. 4 TDC related areas (Own Elaboration)

In these areas, the specific Latin American TDC presents information that deserves to be highlighted. Teachers perceive themselves as more confident with skills [23], [28], [29], [61], [62]. Teachers use technological artifacts (technical management of the computer, projector, video, and image player). Teachers search the Web (selecting relevant information and processing information). Teachers use problem-resolution of general, cultural, ethical, and social responsibility issues. In this sense, these competencies are also mentioned in the European DigCom-Edu model [63].

On the other hand, teachers showed low-intermediate confidence in skills [15], [25], [49]. Teachers use academic management (critical management of available data, comprehension, and creativity, and responsibility). Teachers employ the design of digital teaching resources. Teachers use or reuse of digital media (spreadsheet management, database management, multimedia presentation design). Teachers consider the security of the information. Teachers use social media (ex-change activities, works, and experiences in electronic magazines, sharing experiences, ideas/opinions in virtual spaces, and others). These results concur with studies related to the university context [64]-[66].

\section{CONCLUSION}

In this research, digital technologies' current and future advancement influences and transforms different teachinglearning processes. This has become even more evident with the health pandemic of Covid-19. From the research question, it has been determined that teachers' digital competencies are aligned in areas that need to be strengthened so that their appropriation is evident both for their teaching work and for their professional and personal development. Also, it was established that these competencies should go beyond the instrumental management of technology, focusing on methodological competencies that allow them to demonstrate their digital knowledge, skills, and attitudes. In this sense, the researchers concluded that the areas considered most relevant for the formation of digital teaching competencies are: Knowledge Construction with $28 \%$, and Use of Technology with $26 \%$, which is logical since the primary work of the teacher lies in this function, using technology as an instrument to fulfill his essential task. Next in importance are the Axiological area with 13\%, Professional Development with $13 \%$, Information and Communication with $15 \%$, and Social with 5\%, evidencing their importance and the need to strengthen them, since theoretical knowledge of a given technology does not presuppose its use. On the other hand, teachers should be aware of the possibilities offered by technologies in training processes to share good practices.

Also, this research showed that there is not a high percentage of information on digital competencies in the Latin American context (a total of 16 articles in Latin America). Therefore, this research is an important contribution in this regard. It allowed us to use the reference framework for the development of digital competence at the European level and adapt it to the Latin American context to generate information that can be used for improvement purposes.

Finally, the research conducted leads us to conclude that there is still a long way to go, especially in developing teachers' digital competencies. The main focus of the existing articles is to analyze the participants' self-perception, leaving aside the importance of research and development through teacher training.

Future research is recommended to conduct a new systematic review of the literature in the Latin American context from 2020 to 2023 to contrast the progress made since the pandemic caused by COVID-19 appeared, which led to 
the suspension of face-to-face classes in $90 \%$ of the planet. It is also recommended to analyze digital teaching skills after a training process to compare changes in the teaching performance.

\section{REFERENCES}

[1] A. Azolay, "No Title," 2020. https://en.unesco.org/news/290-millionstudents-out-school-due-covid-19-unesco-releases-first-globalnumbers-and-mobilizes.

[2] N. L. Pereira, H. A. Ferenhof, and F. J. Spanhol, "Strategies for the management of digital competences in higher education: a review in the literature," Rev. Latinoam. Tecnol. Educ., vol. 18, no. 1, pp. 71-90, 2019, doi: 10.17398/1695-288X.18.1.71.

[3] Consejo de la Unión Europea, "Council Recommendation of May 22nd, 2018, on key competences for lifelong learning.," Brussels, 2018.

[4] UNESCO, "Estándares de competencia en TIC para docentes," 2008.

[5] J. Cabero-Almenara and A. Palacios-Rodríguez, "Marco Europeo de Competencia Digital Docente «DigCompEdu». Traducción y adaptación del cuestionario «DigCompEdu Check-In»," Edmetic, vol. 9, no. 1, pp. 213-234, 2019, doi: 10.21071/edmetic.v9i1.12462.

[6] J. Cabero Almenara, M. del C. Llorente Cejudo, and J. A. Morales Lozano, "Evaluación del desempeño docente en la formación virtual: ideas para la configuración de un modelo," RIED. Rev. Iberoam. Educ. a Distancia, vol. 21, no. 1, p. 261, Jul. 2017, doi: 10.5944/ried.21.1.17206.

[7] E. P. Navío, M. M. Domínguez, and J. C. Zagalaz, "Perception of the professional competences of last year's students of pre-primary education and primary education degrees and students of training teachers master," J. New Approaches Educ. Res., 2019, doi: 10.7821/naer.2019.1.344.

[8] M. Spante, S. S. Hashemi, M. Lundin, and A. Algers, "Digital competence and digital literacy in higher education research: Systematic review of concept use," Cogent Educ., vol. 5, no. 1, pp. 121, 2018, doi: 10.1080/2331186X.2018.1519143.

[9] K. Stopar and T. Bartol, "Digital competences, computer skills and information literacy in secondary education: mapping and visualization of trends and concepts," Scientometrics, vol. 118, no. 2, pp. 479-498, Feb. 2019, doi: 10.1007/s11192-018-2990-5.

[10] UNESCO, "Digital skills for life and work Skills for Employment," 2017. Accessed: May 10th, 2020. [Online]. Available: https://www.skillsforemployment.org/KSP/en/Details/?dn=WCMST EST4_193296.

[11] E. van Laar, A. J. A. M. van Deursen, J. A. G. M. van Dijk, and J. de Haan, "The relation between 21 st-century skills and digital skills: A systematic literature review," Comput. Human Behav., vol. 72, pp. 577-588, 2017, doi: 10.1016/j.chb.2017.03.010.

[12] A. G. V. Muñoz-Repiso, S. C. Martín, and V. B. Gómez-Pablos, "Validation of an indicator model (INCODIES) for assessing student digital competence in basic education," J. New Approaches Educ. Res., 2020, doi: 10.7821/naer.2020.1.459.

[13] L. Castañeda, F. Esteve, and J. Adell, "Why rethinking teaching competence for the digital world?," Revista de Educacion a Distancia. 2018, doi: $10.6018 / \mathrm{red} / 56 / 6$.

[14] J. L. L. Cantabrana, M. U. Rodríguez, and M. G. Cervera, "Assessing teacher digital competence: The construction of an instrument for measuring the knowledge of pre-service teachers," J. New Approaches Educ. Res., 2019, doi: 10.7821/naer.2019.1.370.

[15] A. Schleicher, "The Future of Education and Skills: Education 2030," OECD Educ. Work. Pap., 2018.

[16] K. Petersen, R. Feldt, S. Mujtaba, and M. Mattsson, "Systematic mapping studies in software engineering," 2008.

[17] B. A. Kitchenham, D. Budgen, and O. Pearl Brereton, "Using mapping studies as the basis for further research - A participant-observer case study," Inf. Softw. Technol., vol. 53, no. 6, pp. 638-651, 2011, doi: 10.1016/j.infsof.2010.12.011.

[18] M. Peñafiel, R. Navarrete, M. Tenemaza, M. Vásquez, D. Vásquez, and S. Luján-Mora, "The Diffusion of News Applying Sentiment Analysis and Impact on Human Behavior Through Social Media," in Advances in Intelligent Systems and Computing, Jul. 2020, vol. 965, pp. 250-259, doi: 10.1007/978-3-030-20454-9_25.

[19] R. Pérez, "Competencia Digital Docente en los Institutos Superiores de Formación de Maestros: Caso de República Dominicana," PixelBit. Rev. Medios y Educ., vol. 55, no. 1, pp. 75-94, 2019.

[20] K. V. Pozos Pérez and J. Tejada Fernández, "Competencias Digitales en Docentes de Educación Superior: Niveles de Dominio y
Necesidades Formativas," Rev. Digit. Investig. en Docencia Univ., vol. 12, no. 2, pp. 59-87, 2018, doi: 10.19083/ridu.2018.712.

[21] L. Levano-Francia, S. Sanchez Diaz, P. Guillén-Aparicio, S. TelloCabello, N. Herrera-Paico, and Z. Collantes-Inga, "Competencias digitales y educación,” Propósitos y Represent., vol. 7, no. 2, pp. 569578, 2019, doi: 10.20511/pyr2019.v7n2.329.

[22] A. M. V. Martín, G. H. O. Cazco, M. C. González, and F. M. Abad, "Digital competence of the University faculty: Case study of the Universidad nacional de Chimborazo," ACM Int. Conf. Proceeding Ser., vol. 02-04-Nove, no. October 2017, pp. 147-154, 2016, doi: 10.1145/3012430.3012510.

[23] K. Pozos, "Digital competence of higher education teachers for the knowledge society: a preliminary approach of a need assessment study in mexican universities - IATED Digital Library," in 6th International Conference of Education, Research and Innovation, 2013, pp. 55335543, Accessed: May 10th, 2020. [Online]. Available: https://library.iated.org/view/POZOSPEREZ2013DIG.

[24] A. Rangel, "Propuesta De Un Perfil Digital Teaching Skills : a Profile," Pixel-Bit. Rev. Medios y Educ., pp. 235-248, 2015, doi: http://dx.doi.org/10.12795/pixebil.2015.i46.15.

[25] M. S. Prince Machado, G. C. Tenorio Sepúlveda, and M. S. Ramirez Montoya, "Educational innovation and digital competencies: the case of OER in a private Venezuelan university," Int. J. Educ. Technol. High. Educ., vol. 13, no. 1, pp. 1-10, 2016, doi: 10.1186/s41239-0160006-1.

[26] J. Valverde-Berrocoso and J. Balladares, "Sociological approach to the use of b-learning in digital education of university teachers," Sophia, vol. 23, 2017, [Online]. Available: http://doi.org/.

[27] M. C. R. A. Joly, B. D. Da Silva, and L. Da Silva Almeida, "Evaluation of teaching competencies for using digital technologies in communication and information ," Curriculo sem Front., vol. 12, no. 3, pp. 83-96, 2012, [Online]. Available: http://www.scopus.com/inward/record.url?eid=2-s2.084873167711\&partnerID=40\&md5=391c714a9effd759de355243ae9 65350 .

[28] A. O. Tobar Gomez, "Índice de competencias TIC en docentes de educación superior," Campus Virtuales, vol. 6, no. 2, pp. 113-125, 2017, [Online]. Available: www.revistacampusvirtuales.es.

[29] M. S. Ramírez-Montoya, J. Mena, and J. A. Rodríguez-Arroyo, "Inservice teachers' self-perceptions of digital competence and OER use as determined by a xMOOC training course," Comput. Human Behav., vol. 77, pp. 356-364, 2017, doi: 10.1016/j.chb.2017.09.010.

[30] J. Reyes, "Las Competencias Digitales: una necesidad del docente Ecuatoriano del siglo XXI," in Revista Dilemas Contemporáneos. Educación, Politica y Valores., 2018, vol. 6, no. 0, doi: 10.1017/CBO9781107415324.004.

[31] J. E. Revelo Rosero, "Modelo de integración de la competencia digital del docente universitario para su desarrollo profesional en la enseñanza de la matemática - Universidad Tecnológica Equinoccial de Ecuador," EDMETIC, vol. 7, no. 1, p. 196, Mar. 2018, doi: 10.21071/edmetic.v7i1.6910.

[32] A. Mattila, "The future educator skills in the digitization era: Effects of technological development on higher education," Proc. - 2015 5th Int. Conf. e-Learning, ECONF 2015, pp. 212-215, 2016, doi: 10.1109/ECONF.2015.18.

[33] A. L. Padilla-Hernández, V. M. . Gámiz-Sánchez, and M. . A. RomeroLópez, "Validación del contenido de un guion de entrevista sobre la competencia digital docente en Educación Superior," RISTI - Rev. Ibérica Sist. e Tecnol. Informação, no. 32, pp. 1-16, 2019, doi: 10.17013/risti.32.1-16.

[34] M. P. Prendes, I. Gutiérrez, and F. Martínez, "Competencia digital: una necesidad del profesorado universitario en el siglo XXI," Rev. Educ. a Distancia, no. 56, pp. 1-22, 2018, doi: 10.6018/red/56/7.

[35] K. Ala-Mutka, "Mapping Digital Competence: Towards a Conceptual Understanding.," Jt. Res. Cent. - Inst. Prospect. Technol. Stud., 2011.

[36] O. Mas and J. Tejada, "Funciones y competencias en la docencia universitaria," 2013

[37] A. Navio, "Las competencias profesionales del formador," 2005.

[38] F. Esteve and M. Gisbert, "Competencia digital en la educación superior," Rev. Venez. Inf. Tecnol. y Conoc., vol. 10, no. 3, pp. 29-42, 2013, Accessed: May 01, 2019. [Online]. Available: https://dialnet.unirioja.es/servlet/articulo? codigo $=4772632$.

[39] I. Gutiérrez, "Competencias del profesorado universitario en relación al uso de tecnologías de la información y comunicación: análisis de la situación en España y propuesta de un modelo de formación.," 2011.

[40] A. Hernández, "La formación del profesorado para la integración de las TIC en el currículum: nuevos roles, competencias y espacios de 
formación," in Investigación y tecnologías de la información y comunicación al servicio de la innovación educativa., 2008, pp. 3356.

[41] P. Marqués, "Las competencias digitales de los docentes." [Online]. Available: http://peremarques.pangea.org/competenciasdigitales.htm.

[42] "Estándares en Tecnología de la Información y la Comunicación para la Formación Inicial de Docentes de Chile," 2006.

[43] J. C. López, “QQué es la competencia para manejar información (CMI)?," 2007.

[44] M. C. Joly, "Habilidades em tecnologias: avaliação de desempenho docente na Educação Básica,” Martins, R., vol. 13, pp. 75-85, 2008.

[45] “Competencias TIC para el desarrollo profesional docente," 2013.

[46] G. Lorenzo, J. Pomares, and R. Roig-Vila, "Diseño de un modelo de indicadores de competencias TIC en la docencia universitaria."

[47] A. Ferrari, "DIGCOMP: A framework for developing and understanding digital competence in Europe," Publ. Off. Eur. Union, 2013.

[48] K. Aesaert, D. van Nijlen, R. Vanderlinde, and J. van Braak, "Direct measures of digital information processing and communication skills in primary education: Using item response theory for the development and validation," Comput. \&Educatio, vol. 76, pp. 168-181, 2014

[49] M. Gisbert and J. Lázaro, "Professional development in teacher digital competence and improving school quality from the teachers' perspective: a case study," J. New Approaches Educ. Res., vol. 4, no. 2, pp. 115-122, Jul. 2014, doi: 10.7821/naer.2015.7.123.

[50] M. Rieckmann, "Future-oriented higher education: Which key comptencies should be fostered through university teaching and learning, Futures," vol. 44, no. 2, 2012.

[51] A. Granić and N. Marangunić, "Technology acceptance model in educational context: A systematic literature review," British Journal of Educational Technology. 2019, doi: 10.1111/bjet.12864.

[52] J. Jensen, "A systematic literature review of the use of Semantic Web technologies in formal education," British Journal of Educational Technology. 2019, doi: 10.1111/bjet.12570.

[53] M. Brady, A. Devitt, and R. A. Kiersey, "Academic staff perspectives on technology for assessment (TfA) in higher education: A systematic literature review," British Journal of Educational Technology. 2019, doi: 10.1111/bjet.12742.

[54] F. M. Esteve-Mon, M. A. Llopis-Nebot, and J. Adell-Segura, "Digital Teaching Competence of University Teachers: A Systematic Review of the Literature," Rev. Iberoam. Tecnol. del Aprendiz., 2020, doi: 10.1109/RITA.2020.3033225.

[55] A. Sánchez-Caballé, M. Gisbert-Cervera, and F. Esteve-Mon, "The digital competence of university students: A systematic literature review," Aloma. 2020

[56] D. Antonio-Manuel Rodríguez-García, F. R. Sánchez, and J. RuizPalmero, "Digital competence, higher education and teacher training: A meta-analysis study on the Web of Science," Pixel-Bit, Rev. Medios y Educ., 2019, doi: 10.12795/pixelbit.2019.i54.04.

[57] F. J. Fernández-Cruz and M. J. Fernández-Díaz, "Los docentes de la Generación Z y sus competencias digitales," Comunicar, vol. 24, no. 46, pp. 97-105, 2016, doi: http://dx.doi.org/10.3916/C46-2016-10.

[58] C. Redecker, European framework for the digital competence of educators: DigCompEdu. 2017.

[59] "Marco Común de Competencia Digital Docente Octubre 2017." Accessed: May 01, 2021. [Online]. Available: http://aprende.educalab.es.

[60] "Computational Thinking Competencies | ISTE." https://www.iste.org/standards/computational-thinking (accessed May 01st, 2021).

[61] R. Rosero, J. Enrique, R. Domínguez, and F. Ignacio, "Jorge Enrique Revelo Rosero, Francisco Ignacio Revuelta Domínguez y Alicia González-Pérez," vol. 7, no. 1, pp. 196-224, 2018.

[62] J. Solís de Ovando Calderón and V. Jara Jara, "Competencia digital de docentes de Ciencias de la Salud de una universidad chilena," PixelBit, Rev. Medios y Educ., 2019, doi: 10.12795/pixelbit.2019.i56.10.

[63] F. Caena and C. Redecker, "Aligning teacher competence frameworks to 21st century challenges: The case for the European Digital Competence Framework for Educators ( Digcompedu) ," Eur. J. Educ., 2019, doi: 10.1111/ejed.12345.

[64] S. Guri-Rosenblit, "E-teaching in higher education: An essential prerequisite for e-learning," J. New Approaches Educ. Res., 2018, doi: 10.7821/naer.2018.7.298

[65] B. Rivas-Rebaque, F. Gértrudix-Barrio, and J. C. D. C. De Britto, "The perception of the university professor regarding the use and value of open data," Educ. XX1, 2019, doi: 10.5944/educxx1.21317.

[66] M. Bond, V. I. Marín, C. Dolch, S. Bedenlier, and O. Zawacki-Richter, "Digital transformation in German higher education: student and teacher perceptions and usage of digital media," Int. J. Educ. Technol. High. Educ., 2018, doi: 10.1186/s41239-018-0130-1. 